\title{
EPIC and the RUSSIAN NOVEL from GOGOL to PASTERNAK
}

\author{
FREDERICK T. GRIFFITHS \\ and STANLEY J. RABINOWITZ
}

Boston

2011 
Griffiths, Frederick T.

Epic and the Russian novel : from Gogol to Pasternak / Frederick T. Griffiths and Stanley J. Rabinowitz.

p. cm. - (Studies in Russian and Slavic literatures, cultures and history)

Includes bibliographical references and index.

ISBN 978-1-936235-53-7 (hardback: alk. paper) 1. Russian fiction$19^{\text {th }}$ century-History and criticism. 2. Russian fiction $-20^{\text {th }}$ centuryHistory and criticism. 3. Epic literature, Russian-History and criticism. I. Rabinowitz, Stanley J. II. Title.

PG3098.E65G75 2011

891.73'309-dc22

2011006283

Copyright (C) 2011 Academic Studies Press

All rights reserved

ISBN $978-1-936235-53-7$

Book design by Ivan Grave

Published by Academic Studies Press in 2011

28 Montfern Avenue

Brighton, MA 02135, USA

press@academicstudiespress.com

www.academicstudiespress.com 


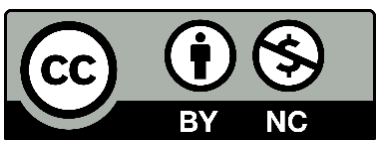

Effective December 12th, 2017, this book will be subject to a CC-BY-NC license. To view a copy of this license, visit https://creativecommons.org/licenses/by-nc/4.0/. Other than as provided by these licenses, no part of this book may be reproduced, transmitted, or displayed by any electronic or mechanical means without permission from the publisher or as permitted by law.

The open access publication of this volume is made possible by:

THE

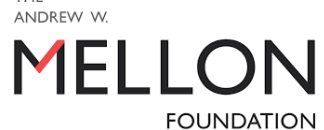

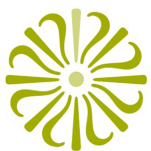

NATIONAL ENDOWMENT FOR THE HUMANITIES

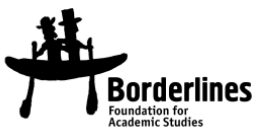

This open access publication is part of a project supported by the National Endowment for the Humanities and The Andrew W. Mellon Foundation Humanities Open Book initiative, which includes the open access release of several Academic Studies Press volumes. To view more titles available as free ebooks and to learn more about this project, please visit borderlinesfoundation.org/open.

Published by Academic Studies Press

28 Montfern Avenue

Brighton, MA 02135, USA

press@academicstudiespress.com

www.academicstudiespress.com 
Studies in Russian and Slavic Literatures, Cultures and History

Series Editor - LaZar Fleishman (Stanford University)

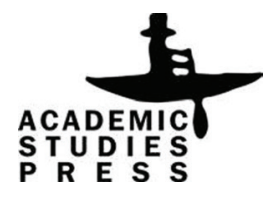

